\title{
Role Playing Activity in English for Business Class for Non-English Study Program
}

\author{
Berlinda Mandasari \\ Universitas Teknokrat Indonesia \\ berlindamandasari22@gmail.com
}

\begin{abstract}
This research studies about role playing activity in English for business class at Universitas Teknokrat Indonesia. English for business is a compulsory subject for non-English study program. The objectives of this study are to identify the students' attitude toward role palying activity in the class and the implementation of role play in the class. 45 students from informatic engineering study program who take English for business are the participants of this research. Data are collected through questionnaire, interview and observation which are then analyzed and tabulated. The result of this study shows that most students have positive attitudes toward role playing activity during studying English for business. knowing their role in a given situation based on topics being learnt in the class and playing the role ease them to practice speaking English and improve their English ability. Students are also motivated to learn English since the activity is enjoyable for them.
\end{abstract}

business; attitude

Key words - Role playing; English for

\section{INTRODUCTION}

English plays important role for global communication and is recognized as an international language which is used in academic and occupational field. The development of technology nowadays has influenced English language teaching. instead of technology, the development in science and economics require to use English as media to communicate among expertists around the world. It attracts the course designers to change the use of general English into English fo specific purpose. This English for specific purposes refer to an approach of language learning which lead the learners meet the purpose of why they need to learn the target language. The traditional teaching of ESP has generally focused on the delivery of language information through reading comprehension, writing, vocabulary and grammar exercises neglecting the need to integrate it with skills [1]. However, they believe that interactive teamwork, critical reading and writing, communication skills, negotiation, presentations are some of the vital soft skills for today's academic and future work environment [2]. Foreign languages have been learned not for their own sake but as vehicles for social and economic contacts and for the transportation of ideas. [3]

In Indonesia, English has been taught in schools and becomes compulsory subject for high school and higher school. Educators are facing some challenging in teaching English since English is not used for daily conversation. Teaching activity done by teacher will be influenced by teaching technique and the perception of that technique. There are many techniques that can be used to teach English, they are gaming, discussion, role play and presentation. Related to the need of English as specific purpose, some private universities in Indonesia put English in their curriculum as a compulsory subject to be learnt. Students from some study program will learn English based on their needs. It also works in Universitas Teknokrat Indonesia in which first and second semester students from information system are oblidged to take English for business to full fill their English needs. The materials are practical, which mean that the students need to practice speaking English by doing some role. This is the reason in which most lecturers use role play activity as an effective technique to teach students. A role play is done when students take the part of particular person; a manager, a shop assistant. They act out the conversation. They do it unscriptedly, in which they do not prepare the script but they have prepared the ideas [4]. It means that role play has number of possibilities for communication practice. Role play provides learners to practice speaking English before they do it in real situation. Besides, students also learn in an imaginary situation which is designed as real situation to develop their English ability. This situation will lead students to use English in real life.

Since role play has been implemented in the class, it is expected that students can get the basic knowledge of English and help their academic life. However, it is important to know what students' expectation from it? what do they think toward role play in English language learning? Since teaching English is now Student- 
centered, it is essential to know their perception toward language they have learnt in the class.

\section{RESEARCH DESIGN}

This is a qualitative study. This research aims at identifying students' attitude toward role playing activity in the class and how role play technique is implemented. the researcher used questionnaire in the form of likert scale and interview to gain data. The data is then analyzed by using descriptive analysis. There are 45 students as the participants in this research. The questionnaire consists of 16 statements about their attitude toward role playing activity.

\section{FINDINGS}

Students are assigned to do role playing activity as customer service in some public places and telephoning. Besides, they are also assigned to act as the manager of a company that present company profile. These materials are part of English for Business subject that they have to accomplish. From these activity, the researcher tried to identify students' attitude toward activity they have done and the implementation of role play in the class. The finding of research is described in the following paragraph.

\section{a. Students' Attitude}

The result of questionnaire showed that most students enjoy studying English through role play. The respondent responses $(84 \%)$ "strongly agree" and "agree". They agreed that learning English through role play is fun and enjoyable. Since the students have to prepare themselves for their best performance in playing the role, they thought that it is challenging to prepare it. Because it is challenging, the students are motivated to learn English. It can be seen from the result of the questionnaire in which 36 respondents or $80 \%$ of total respondents responses "strongly agree" and "agree". It is also strengthened by the result of questionnaire. Student A response whether they are motivated or not when studying English by using role play technique. The response is as follow.

$$
\begin{aligned}
& \text { "Sangat termotivasi sekali, sekarang sangat } \\
& \text { bersemangat sekali dalam belajar bahasa } \\
& \text { inggris" } \\
& \text { (I am really motivated and eager to learn } \\
& \text { English").-student 1- }
\end{aligned}
$$

The other student response:

"Ya, karena setelah saya melakukannya saya merasa senang dan termotivasi untuk menghafal vocab inggris agar saat ada tugas peran saya tidak kesulitan".
(Yes, I am happy and motivated to memorize vocabularies in order that I will not get difficulty during practicing role play).-student2-

A role-play uses different communicative techniques and develops fluency in the language, promotes interaction in the classroom and increases motivation [5]. Peer interaction has a range of motivational and social benefits. These include: interacting with peers is more interesting than listening to lectures, improves communication skills, increases selfawareness and also provides opportunities for forming relationships [6]. Role playing can be effectively used in the classroom to motivate and engage students, enhance current teaching strategies, provide real world scenarios to help students learn, learn skills used in real world situations (negotiation, debate, teamwork, cooperation, persuasion), provide opportunities for critical observation of peers [7].

Role-plays are important in the communicative approach because they give learners an opportunity to practice communicating in different social contexts and different social roles [8]. A role-play is a highly flexible learning activity, which has a wide scope for variation and imagination. Thus, role play can improve learners' speaking skills in any situation, and helps learners to interact. For the shy learners, role play helps by providing a mask, where learners with difficulty in conversation are liberated .In addition, It is fun and most learners will agree that enjoyment leads to better learning.

$20 \%$ respondents response "disagree" toward the statement that role play motivates students. They got difficulty to memorize English vocabulary so that they got difficulty to perform the play. It can be seen from the result of questionnaire below.

"Saya kurang termotivasi karena kata-kata dalam bahasa Inggris sulit untuk dihafal".

(I am not motivated because English vocabulary is difficult to memorize) -student 4-

Students agree that role playing activity improve their English ability. It can be seen from that data that $91 \%$ of total respondents (41 students) agree on the statement that role play improve their English ability. Through role playing activity, they knowledge is also improved. 93\% respondents agree that their knowledge about English and role they play has improved. It can also be seen from the result of questionnaire whether there is improvement on their English.

"Ada, salah satu nya yaitu peningkatan kemampuan dalam hal berbicara dalam bahasa inggris". (the improvement is on my speaking ability). -student 1- 
"Sangat meningkatkan kemampuan bahasa Inggris setelah mendapat pembelajaran tersebut". (Role play improves my English ability)-student 2-

Role play can improve learners' speaking skills in any situation and helps learners to interact. Role play puts students in situation in which they are required touse and develop those phatics forms oflanguage which are so necessary in oiling the works of social relationships. Students need to prepare their role in English [9]. it is helpful for students to have tried out and experimented with language they will require in the friendly and safe environment of a classroom. Role play helps many shy students by providing them with a mask.

Role play provides students with new epressions and vocabulary. The data of questionnaire showed that $77 \%$ respondents (35 students) agree that they get some new vocabulary after doing role playing activity. Since the activity is scripted role play, students need to know the meaning of each expression written. Knowing the meaning of each expression and vocabulary will enable students to play the role and conduct conversation easily. It can be seen from the result of interview whether they learn new vocabulary and expression.

"Iya. Saya mendapatkan banyak kosakata baru yang belum pernah saya dengar sebelumnya. Jadi saya cari artinya dulu sebelum praktek supaya saya mudah mempraktekkan percakapan itu". (I get a lot of new vocabulary that I have never known before. I find out the meaning before I practice the play) -student 3-

Role-playing develops learners ${ }^{\text {ee }}$ fluency in speaking [10]. The wide range of language functions, for example apologising, greetings, etc., is exercised more than in any other activities. Learners' focus is put on the communication of meaning rather than on the appropriate use of language. Therefore, through role-playing teachers may train students' speaking skills in any social situations. It means that learners are put in conditions which require speech that is used to communicate socially more than the language necessitated by teaching syllabuses.

Role play helps those shy students to overcome their shyness. $66 \%$ respondents respond "disagree" that they feel shy to perform the play. It means that more than a halp students feel free and enjoy practicing and performing their role. They are not shy on it. This is the advantage of role play in which role-playing is that learners are given a chance to pretend someone else. Such a technique may help timid students to overcome their shyness of speaking [11]. Reticent students often have difficulty talking about their experiences or about themselves. The fact that they are someone else makes them feel that their own personality is not implicated. Students can become anyone they like for a short time. Students can also take the opinion of someone else. Functional language of scenarios can be activated and practiced through role play in imaginary situation. It aims at encouraging students thinking and creativity, letting students develop and practice new language and behavioral skills in a relatively non-threatening setting and can create the motivation and involvement necessary for learning to occur.

b. Implementation of Role Play

In the interactional class, role play was conducted by performing some role of an employee in certain company that they have prepared before. There are three topics in English for Business class that theyhave to present by using role play. They are practicing customer service, telephoning and presenting company profile. In customer service topics, students have to pretend themselves as a receptionist and a guests. They act them out. In presenting company profile, students have to act themselves as the manager of certain company that introduce the company profile. At glance, students performances were good. They can act their role well. However, there are some mistakes that the researcher notice. They commonly did mistakes in grammar and pronunciation. After the students finished performing the play, lecturer gave comment and feedback which is later on beneficial for students to perform the play better.

Basically, students satisfied with their performance in role play. The data from the questionnaire stated that $77 \%$ respondents satisifed with their performance. They conduct conversations and act as if they were someone they act out. Putting pupils into pairs for doing the dialogues is a simple way of organizing even large classes. Dialogues, which involve some sort of action or movement, are the ones which work best with the pupils. Intonation is terribly important too, and pupils love to play around with it [12]. Students pretend that they are in various social contexts and have a variety of social roles. In roleplay activities, the teacher gives information to the learners such as who they are and what they think or feel. Thus, the teacher can tell the student "You are David; you go to the doctor and tell him what happened last night." [13]. In role play the pupils are pretending to be someone else like the teacher, or a shop assistant, or one of their parents, etc. " One way of getting student to speak in different social context and to assume varied social roles is to use role-play activities in the classroom.Role plays can be performed from prepared scripts, created from a set of prompt 
and expression or written using and consolidation knowledge gained from instruction or discussion of the speech act and its variations prior to the role plays themselves.

\section{CONCLUSION}

Role play is an effective technique to teach English to non-English study program. This technique encourages and motivates students to learn English. Students enjoy the learning process since they play someone else role. A great majority students think that role play improve their English ability. Through preparing the script before performing the play, students are automatically learn the vocabulary used for the play. Then they recognize vocabulary that they haven't ever known before. In general, the respondents show positive attitude toward role play technique. Only a few students feel shy to perform the play in front of the class. The implementation of role play in the class is done well. However, there were some mistkes in the form of grammar and pronunciation. Feedback and comments from lecturers must be given to make students perform the best.

\section{REFERENCES}

[1] Nunan, David. 2003. Practice English language teaching. New York: McGraw-Hill companies.

[2] Johnson, Keith \& Morrow. 1983. Communication in the Classroom.England: Pearson Education Ltd.

[3] Kirgloz, Y. 1999. Identifying learners' lexical needs through computer analysis of texts language journal Vol.83.

[4] Roger Gower, et-al, Teaching practice: A handbook for teacher in training. Oxford: McMillan education 2005. p.105.

[5] Ladousse, Gillian Porter. 1995. Role Play: Resources Book for the teacher series. New York: Oxford University Press.

[6] Biggs, J. 2000. Teaching for quality learning at university Buckingham: SHRE a.nd Open University.

[7] Bonwell, C. C., \& Eison, J. A. 1991. Active learning: Creating excitement in the classroom. Washington, DC: The George Washington University.

[8] Freeman. 2000. Techniques and Principle Teaching. Oxford: Oxford University Press.

[9] Ladousse, Gillian Porter, 1995. Role Play: Resources Book for the Teacher Series. New York: Oxford University Press.

[10] Kowalska, Barbara. 1991. Let them talk in English. Warszawa:WydawnictwoSzkolne i Pedagogiczne.

[11] Ladousse, Gillian Porter. 1995. Role Play: Resources Book for the teacher series. New York: Oxford University Press.

[12] Scott ET, A.W and Ytreberg, L.H. 2003. Teaching English to Children. Longman Group: UK Limited.

[13] Harmer, Jeremy. 2007. How to Teach English. Harlow: Pearson Education Limited.

[14] Stocker, D, English Language Teaching Articles: ESL Role-play. Retrieved July 19, 2017, from http://www.eslbase.com/articles/roleplay.a sp, 2000 